\title{
Chicken housing among the rural community of Tonj County in South Sudan: Types and designs
}

\author{
Jubara A. S. ${ }^{1 *}$, Danga J. ${ }^{2}$, Deng J. A. ${ }^{1}$ and Ochi E. B. ${ }^{3}$ \\ 1Department of Clinical Studies, College of Veterinary Science, University of Bahr El-Ghazal, South Sudan. \\ ${ }^{2}$ Faculty of Agricultural Science, Catholic University of South Sudan, South Sudan. \\ ${ }^{3}$ Department of Clinical Studies, School of Veterinary Medicine, University of Juba, South Sudan. \\ ‘Corresponding author. Email: asjubara@yahoo.com/wpitia1@gmail.com
}

Copyright @ 2021 Obongekpe. This article remains permanently open access under the terms of the Creative Commons Attribution License 4.0, which permits unrestricted use, distribution, and reproduction in any medium, provided the original work is properly cited.

Received 18th August, 2021; Accepted 15th September, 2021

\begin{abstract}
Rural communities usually exert talents and arts in the construction of chickens' shelters as a token for chickens' contributions to their livelihoods worldwide. A purposive cross-sectional study was conducted to highlight types and designs of rural chickens' houses among the village/Boma communities in Tonj County, South Sudan. A total of 400 (four hundred) households owning chickens were randomly selected from 4 (four) villages for the study. A stratified randomized sample collection method, direct interview, enumeration and observations were used. Observations revealed that $271(67.75 \%)$ of the households built houses above the ground level compared to $129(32.25 \%)$ that built close to the ground level. $117(43.17 \%)$ of the households preferred the dome shaped design houses, meanwhile 192(48\%) frequently utilized bamboos for constructing the houses. The study concluded that high proportion of rural community was aware of the importance of housing to chickens. Furthermore, the dome shaped design and the bamboos were preferred for chickens' houses. Farmers Field School (FFS) is needed for educating households to develop inclusive housing structures that realize more benefits and disseminate reciprocation of such study elsewhere in similar rural settings of South Sudan.
\end{abstract}

Keywords: Bamboos, housing, rural chickens, rural communities, Tonj County.

\section{INTRODUCTION}

Chickens provide inexpensive animal protein and income generation to rural communities worldwide. In South Sudan, poultry population has been estimated at 5.6 million birds (GoSS/MARF, 2006) and 6.568 million (CAMP, 2013). Indigenous chicken breeds are distributed all over the country including large Baladi, Bare-neck and Betwil. However, Baladi breed is the most common type with adult weighing 1.350 to $1.362 \mathrm{~kg}$. Indigenous chicken ecotypes have been reared in different ecological zones of the country in urban, peri-urban and rural settings since time immemorial, with the purposes of chicken production for cash income, household consumption, and extra farm activity in addition to their use for cultural/religious ceremonies and as gifts. Mbuza et al. (2017) have shown that the sale of live chickens poses the first important function of rearing chicken in Rukomo sector Nyagatare districts of Rwanda.
Apparently, village chicken production systems are characterized by low levels of inputs and outputs. Hence, harness the potential of village chickens needs a new approach aiming at increasing flock productivity through delivering quality extension services, skills training and controlling poultry diseases (Kitalyi, 1998). Proper housing must not only provide an environment that moderates environmental impact but also adequate ventilation for birds to lay eggs in nest boxes, as well as to feed and sleep in comfort and security (Smith, 1992). Lack of adequate housing can partly explain chicken mortalities and thus good housing is a prerequisite for any viable and sustainable chicken project. Provision of chickens' night shelters in rural areas of Africa has been reported (Moreki, 2010). Moreover, Saki et al. (2012) have reported that almost all farmers provide night shelter for their chickens either in part of the kitchen (1.36\%) or in the main house 
$(39.07 \%)$, in hand-woven baskets $(7.29 \%)$, in bamboo cages $(1.51 \%)$ or in separate sheds purposely made for chickens $(50.77 \%)$. Adult birds and growers are often provided with elevated night housing. Keeping chickens at residential houses has been one of the strategies to prevent the chickens from thieves and predators as well as diseases and pests (Dinka et al., 2010). However, absence of specialized shelter for chicken has exposed the birds to bad weather conditions, predators and diseases culminating in high mortality rates, particularly among chicks (Marwa et al., 2018., Sambo et al., 2015., Olwande et al., 2010). In midland agro-ecological zone of northern Ethiopia, about $42.5 \%$ of female headed households have indicated that the highest loss of chickens is due to predation (Alem, 2014). In Zimbabwe, evidence has shown that provision of housing remains at a rudimentary stage with little importance being attached to the type of housing (Mlambo et al., 2011; Muchadeyi et al., 2007). Nevertheless, studies have revealed that the security remains unabated as main reason for providing housing at night in Sudan (Khalafalla et al., 2000) and South Africa (Swatson et al., 2003). The type of housing varies from wooden to brick structures, but a few cases of steel cages were observed.

Now days, proven lucrative markets for indigenous live chickens are rapidly growing in larger towns of South Sudan as a result of consumers' preference to the taste and organic features of free scavenging source of indigenous chickens over chicken's meat from conventional farms (Lado et al., 2020). Although traditional chickens' production has been present throughout villages of South Sudan, as well as in some towns, information is lacking about the husbandry practices especially housing in the literature. Therefore, this study highlights the types, designs and materials used for the construction of indigenous chickens' houses among Tonj rural farming communities as a token of appreciation to what they get from chickens' products for effective contribution and position of chickens to the livelihoods of households.

\section{MATERIALS AND METHODS}

\section{Study area}

Tonj County is located in northwestern South Sudan, lying approximately 525 kilometers northwest of Juba, 108 kilometers northwest of Wau town. The County lies at $7.274^{\circ} \mathrm{E}$ latitude and $28.677^{\circ} \mathrm{N}$ longitude with elevation of 1. 44 feet. It is the ancestral home to the Dinka and Bongo ethnic groups along with several smaller tribal groups. The people of Tonj preserve much of their cultural identities and traditions with limited interaction with the city. It is relatively uninfluenced by large scale urbanization. The population of Tonj was estimated at 17,340 (National Bureau of Statistics, 2008). The annual rainy period lasts for 8 months from March to November with at least rainfalls of 0.5 to 6.6 inches and temperature ranging between 20 to $40^{\circ} \mathrm{C}$.

\section{Study design and population size}

A cross sectional study in which stratified randomized sample collection method was used. A total of 400 (four hundred) households owning chickens were purposively selected in four (4) Bomas of Tonj County for study.

\section{Data collection}

Direct interview, enumeration and observations were used for data collection.

\section{Data management and analysis}

Data were managed in Microsoft Excel. Descriptive statistics was used for data analysis. Frequencies, percentages and means were presented (Larson and Farber, 2006).

\section{Ethical considerations}

Letters permitting conduction of this study were obtained from local government administration and Ministry of Agriculture and Animal Resources (MAAR). Individual household's consent was obtained prior to commencing the study. The study was approved by the University of Bahr El-Ghazal Ethical Committee vide Certificate No: UBG/EC.RA.12.

\section{RESULTS}

\section{Types and designs of night shelters}

Tables 1 and 2 show a total of 400 households rearing chickens from four Bomas of Tonj County. Of these, the majority of households (67.75\%) built chickens' houses Above the Ground Level (AGL) as shown in Plates 1, 2, 3 $4,8,9,10$ and 11 compared to the minority of $32.25 \%$ that built at Ground Level (GL) as shown in Plates 5, 6, and 7 . Most households $(43.17 \%)$ preferred to construct dome shaped (Plates $3,4,6$ ) and $32.84 \%$ pyramidal designs (Plates 1, 2, and 11). Rectangular (Plate 10) and other irregular designs (Plates 8 and 9), represent the least designs encountered in this study.

\section{Materials used for the construction of chickens' houses}

Most households (48\%) used the commonly available local 
Table 1. Types and designs of chickens' night shelters $(n=400)$ in Tonj County, South Sudan.

\begin{tabular}{|c|c|c|c|c|c|c|c|}
\hline \multirow{2}{*}{ Level } & \multirow{2}{*}{$\begin{array}{l}\text { Frequency } \\
\text { (No.) }\end{array}$} & \multirow{2}{*}{$\begin{array}{c}\text { Percentage } \\
(\%)\end{array}$} & \multicolumn{4}{|c|}{ Shape } & \multirow{2}{*}{ Total } \\
\hline & & & Dome & Pyramidal & Rectangular & Others & \\
\hline Above the ground level (AGL) & 271 & 67.75 & $117(43.17 \%)$ & $89(32.84 \%)$ & $25(9.23 \%)$ & $40(14.76 \%)$ & 271 \\
\hline Ground level (GL) & 129 & 32.25 & $84(65.12 \%)$ & $37(28.68 \%)$ & $8(6.20 \%)$ & - & 129 \\
\hline Total & 400 & 100 & $201(100 \%)$ & $126(100 \%)$ & $33(100 \%)$ & $40(100 \%)$ & 400 \\
\hline
\end{tabular}

Table 2. Local materials used for the construction of chickens' shelters in Tonj County, South Sudan.

\begin{tabular}{lcccc}
\hline Local materials used & Frequency $(\mathbf{n}=\mathbf{4})$ & Total & Percentage $(\%)$ & Mean \pm SD \\
\hline Bamboos & $34,52,46,60$ & 192 & 48 & $48 \pm 10.9$ \\
Green bricks & $23,41,16,14$ & 94 & 23.4 & $23.5 \pm 12.3$ \\
Grass & $23,12,10,8$ & 53 & 13.3 & $13.3 \pm 6.7$ \\
Clay & $3,4,3,6$ & 16 & 04 & $4.0 \pm 1.4$ \\
Mixed & $8,7,2,7$ & 24 & 06 & $6.0 \pm 2.7$ \\
Corrugated iron sheet & $4,8,5,4$ & 21 & 05.3 & $5.3 \pm 1.9$ \\
Total & 400 & 400 & 100 & \\
\hline
\end{tabular}

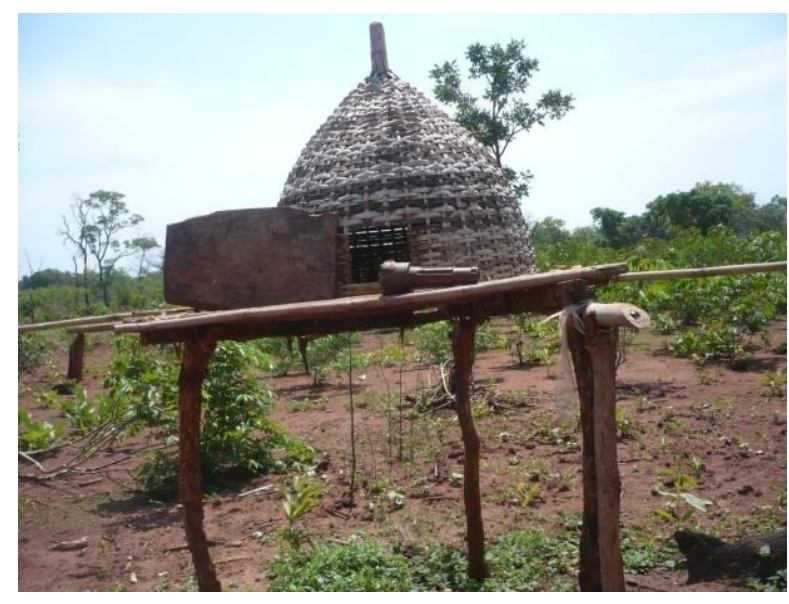

Plate 1. Above the ground pyramidal shape house made up of bamboos.

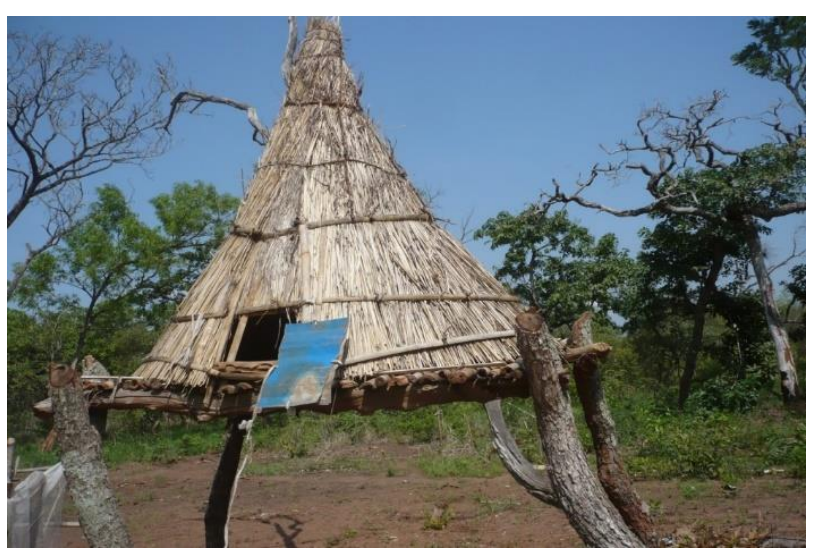

Plate 2. Above the ground pyramidal shape house roofed with grass.



Plate 3. Above the ground, dome shape made of bamboos.

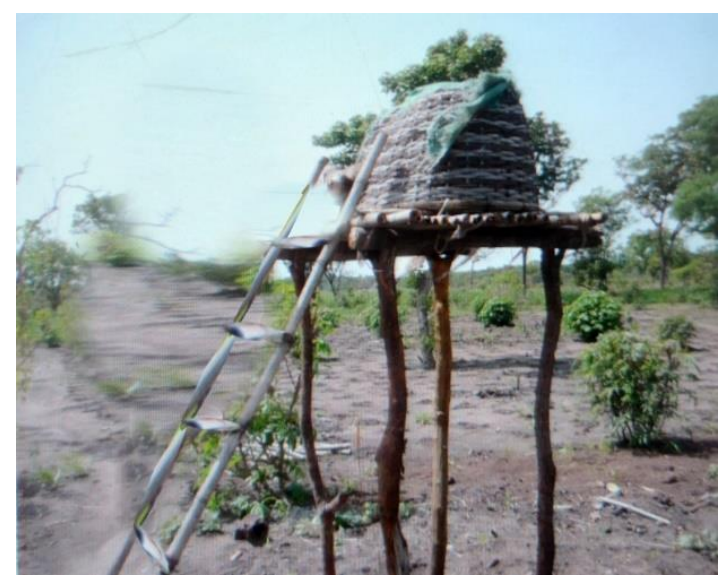

Plate 4. Mixed above the ground dome shape made of bamboo covered with plastic sheet. 


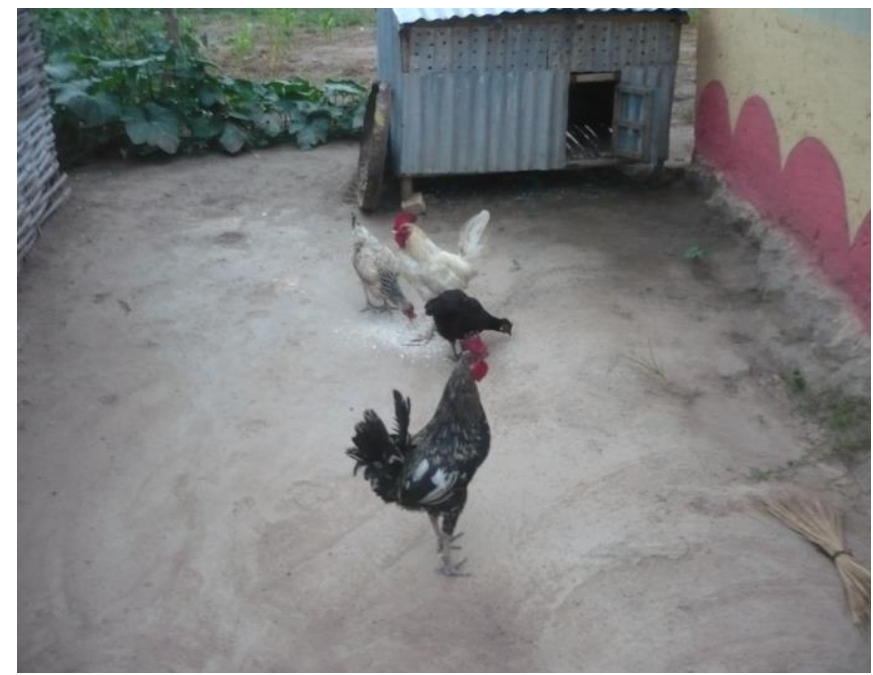

Plate 5. Ground level rectangular shape made of corrugated iron sheet.

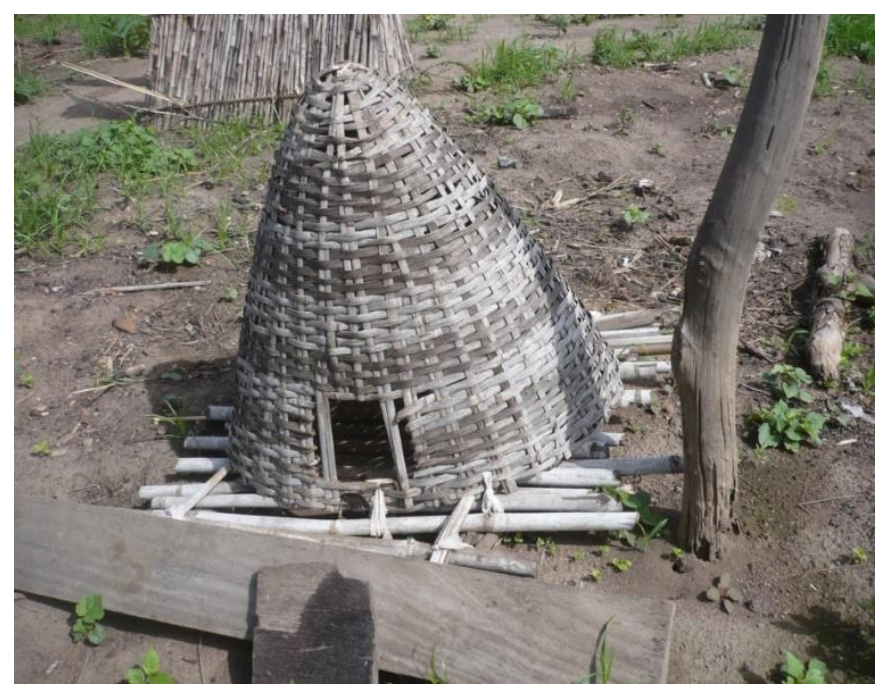

Plate 6. Ground level pyramidal shape made of bamboos.

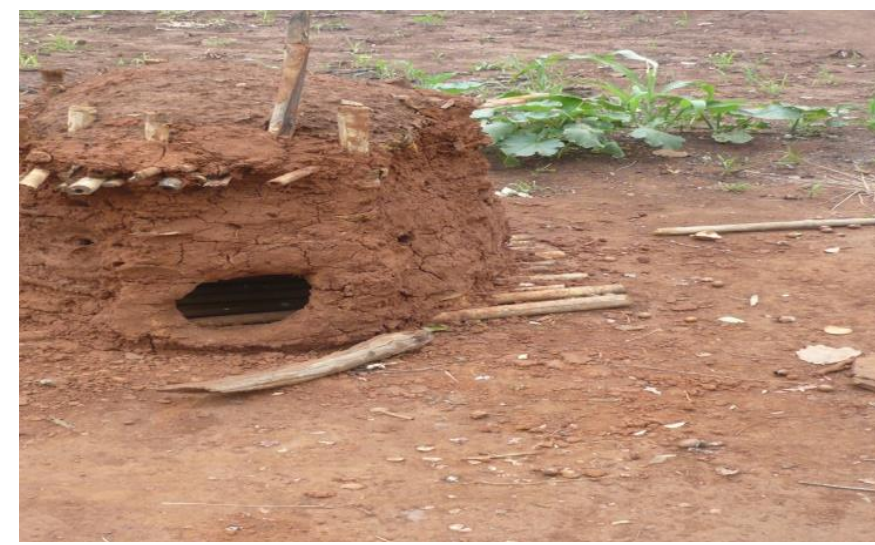

Plate 7. Ground dome shape made of clay.

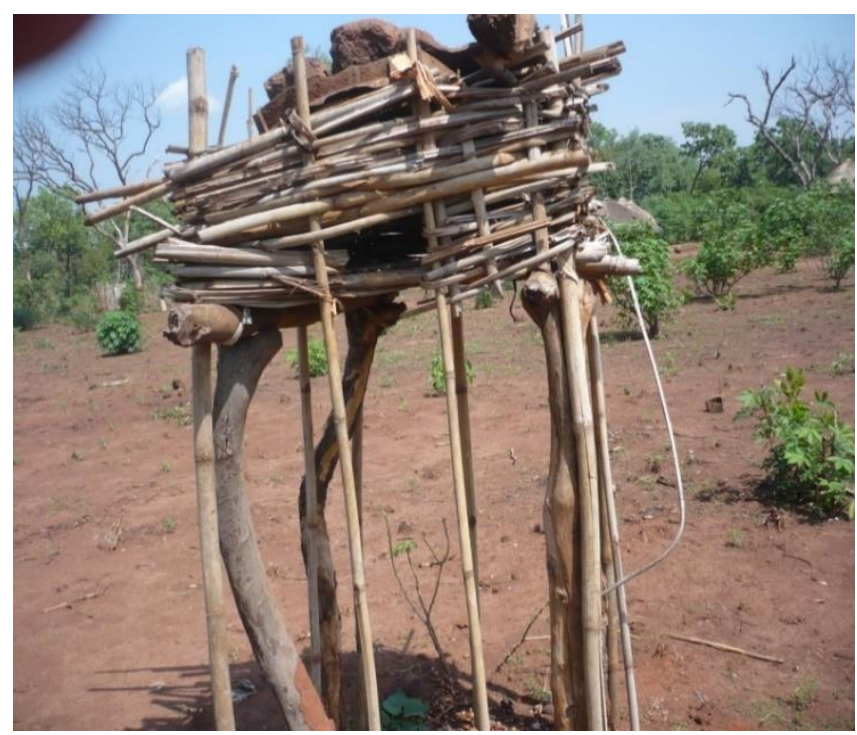

Plate 8. Above the ground unidentified design made of bamboos and clay bricks.

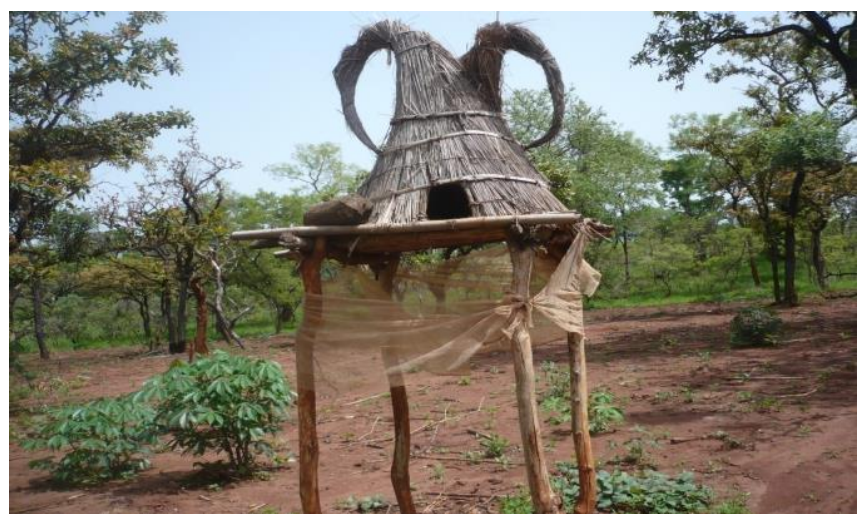

Plate 9. Above the ground horns style shape roofed with grass and mosquito's net.

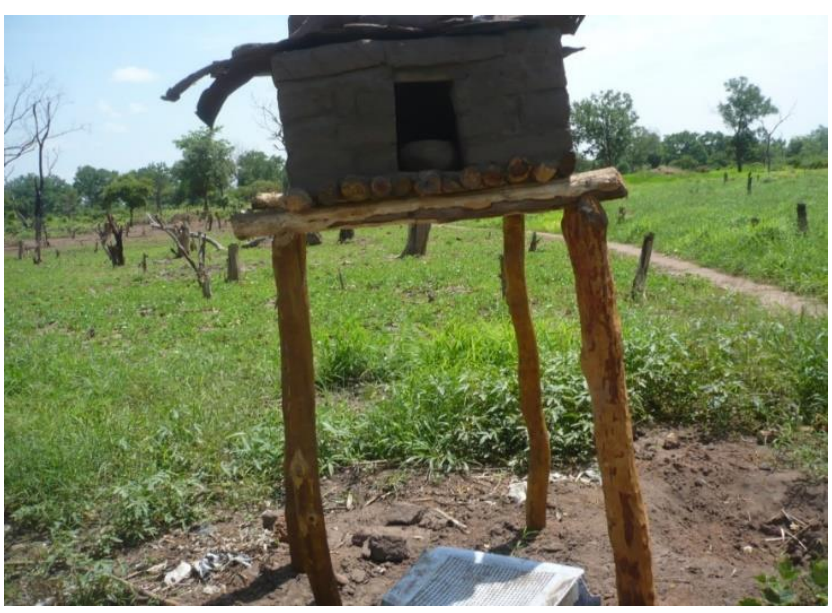

Plate 10. Above the ground rectangular shape made of raw bricks. 


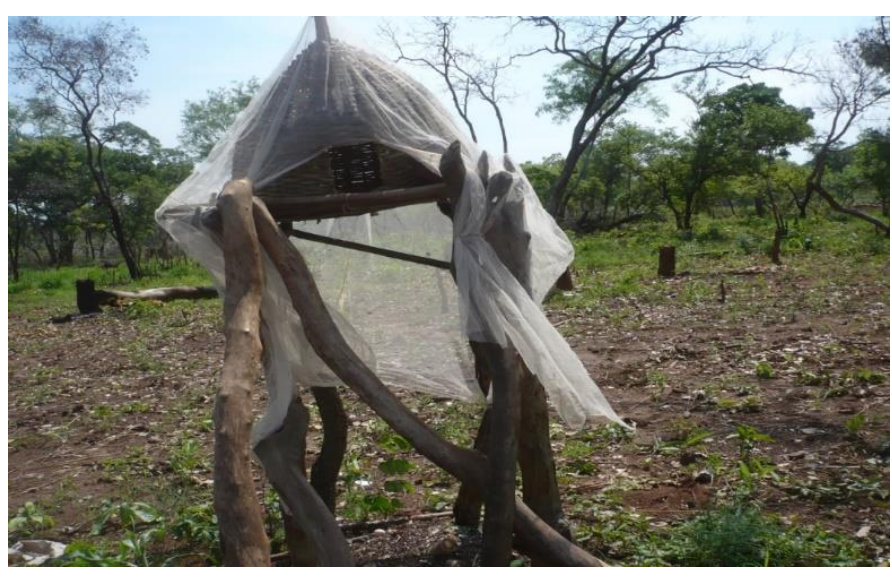

Plate 11. Mixed above the ground Pyramidal shape made of bamboo covered with mosquito's net.

materials such as bamboos (Table 2). Other local materials such as green bricks, clay, grass or mixture with other materials such as mosquitoes' nets were also utilized in less proportion (Plates 2, 7, and 9,10, and11).

\section{DISCUSSION}

Evidence has shown that good housing practice is a prerequisite for any viable and sustainable chicken production project. Appropriate chicken housing could ameliorate environmental impacts and provide amicable ventilation and security for chicken comfort (Smith, 1992). In contrast, absence of specialized shelter for chickens might expose them to detrimental environmental conditions, diseases and predations, culminating in high mortality rates (Marwa et al., 2018., Mlambo et al., 2011; Olwande et al., 2010). Not surprisingly that the Dinka and Bongo are the main indigenous ethnic groups occupying Tonj County. The former are pastoralists rearing cattle, sheep and goats and the later engage in agriculture and rearing of local chickens with some few goats as part of their main domain. Thus, they represent majority of households selected for the study. Interestingly, Bongo ethnic group considers that building a house/shelter for chicken is an art, taste and attitude driven by tangible contributions of chickens' sales to household's economy and poverty alleviation (Jubara et al., 2021). In the rural communities of Tonj County, money accrued from sales of live chickens was the main drive for rearing chickens. This is in line with the findings of Mbuza et al. (2017) in Rukomo sector, Nyagatare District of Rwanda.

Seemingly, this study showed that all the selected households provided housing for their chickens. This is in line with the study of Swai et al. (2007) in Tanga, Tanzania as reflected by the households' awareness on the importance of housing for chickens. However, the study was on the contrary to the findings of Marwa et al. (2018) in Babati District in Tanzania in that only $17.1 \%$ of households kept their chickens in purposively built shelters. In the present study, majority of households (67.75\%) built chickens' houses Above the Ground Level (AGL) as means of protecting them against predators, reduction of theft and security. This is similar to studies revealed by Muchadeyi et al. (2007), Swatson et al. (2002) and Khalafalla et al. (2000). Some households have believed that building an elevated house mimic the comfort of birds on the trees. However, some households built two houses for chickens one AGL and at the GL. The GL house is utilized for laying, brooding, hatching and rearing chicks to the age accessible to houses above the ground. Furthermore, some households covered the poles of houses AGL by mosquito nets or any other rough material to prevent snakes, rats and other predators from accessing entry to the chickens' houses (Plates 11 and 13). Consequently, chicken' houses built close to the GL are suitable for hens with young chicks that cannot enter an elevated house. However, flooding by rain's waters, easy accessibility by predators such as snakes, rats, dogs and among many others were recorded to be a nuisance and major disadvantage of the GL houses. These stood as strong justification for fewer households (32.25\%) that built chickens' houses at the GL. As a remedy, drainage is to be dug around such a house or to raise the floor so that it stays dry during the rainy season. Materials utilized in building chickens' houses varied from Bamboos, wood, grasses, bricks and clay. This has eventually concurred with the reports of Swatson et al. (2002) and Khalafalla et al. (2000) in South Africa and Sudan, respectively. Bamboo trees are more commonly used local materials as such most households made use of these trees in building chickens' houses. Additionally, bamboos are available, affordable, accessible, durable and long lasting trees compared to grass made houses. Furthermore, bamboos are less termite ants-infested trees and can be painted with tar to eliminate insects compared to other materials used.

\section{Conclusion}

Chickens in Tonj County are kept primarily to generate income for different purposes such as children school fees, health care, purchase of farming inputs and equilibrate benefits and risk during draught and crop failure. Households were keen to build different types and designs of chickens' houses as a token to chickens effective contribution to their livelihoods and poverty alleviation. They preferred dome shaped design and to build houses AGL utilizing the most common available affordable and accessible materials.

\section{Recommendations}

1. Challenges facing rural chickens' production must be studied and well documented before attempting any technological intervention for improvement. 
2. Furthermore, establishment of Farmers Field School (FFS) in the County is highly recommended to educate the rural households in the development of inclusive ecosystem housing structures to realize more benefits, and disseminate and reciprocate this study elsewhere in similar rural settings of South Sudan.

\section{CONFLICT OF INTEREST}

Authors declare that there is no conflict of interest.

\section{REFERENCES}

Alem, T. (2014). Production and reproduction performance of rural poultry in lowland and midland agro-ecological zones of central Tigray, Northern Ethiopia. African Journal of Agricultural Research, 9(49), 3531-3539.

CAMP (2013). Livestock sector team, CAMP situation Analysis, Sudan Government, 1955.

Dinka, H., Chala, R., Dawo, F., Bekana, E., \& Leta, S. (2010). Major constraints and health management of village poultry production in Rift Valley of Oromia, Ethiopia. AmericanEurasian Journal of Agricultural and Environmental Science, 9(5), 529-533.

GOSS/MARF. (2006). Animal Resources Sector Policy and Strategic Plan (ARSP) 2006-2011. Government of Southern Sudan (GOSS), Ministry of Animal Resources and Fisheries (MARF), Juba.

Jubara, A. S, Danga, J, Jaja, L. K, Jong, A. D., \& Ochi, E. B. (2021). Rural chicken management practice in South Sudan: Prospects for poverty alleviation and socio-economic development. East African Scholars Multidisciplinary Bulletin, 4(6), 67-74.

Khalafalla, A.I., Awad, S., \& Hass, W. (2000). Village poultry production in Sudan: Characteristics and parameters of family poultry production in Africa. Results of a FAO/IAEA coordinated research programme. Retrieved from https://inis.iaea.org/search/search.aspx?orig_q=RN:3706248 7.

Kitalyi, A. J. (1998). Village chicken production systems in rural Africa household food security and gender issues. Food and Agriculture Organization of the United Nations, FAO, Rome, p.142.

Lado, M. M., Mogga, I. J., Ochi, E. B., \& Abdalla, A. M. (2020). A case study of poultry marketing and trade in Juba County Central Equatoria State, South Sudan. International Journal of Multidisciplinary Research and Development, 7(7),120-123.

Larson, R., \& Farber, B. (2006). Elementary Statistics (3rd edition). Pearson, Prentice, London, UK.

Marwa, L. J., Mbaga, S. H., Mutayoba, S. K., \& Lukuyu, B. (2018). The productivity and management systems of free range local chickens in rural areas of Babati District, Tanzania. Livestock Research for Rural Development, 30(8). Retrieved from http://www.Irrd.org//rrd30/8/leon30134.html.
Mbuza, F., Manishimwe, R., Mahoro, J., Simbankabo, T., \& Nishimwe, K. (2017). Characterization of broiler poultry production system in Rwanda. Tropical Animal Health and Production, 49, 71-77.

Mlambo, T., Mbiriri, D. T., Mutibvu, T., \& Kashangura, M. T. (2011). Village chicken production system in Zhombe communal area of Zimbabwe. Livestock Research for Rural Development, http://www.irrd.org//rrd23/7/mlam23154.htm.

Moreki, J. C. (2010). Village poultry production in SerowePalapye sub- district of Botswana. Livestock Research for Rural Development, 22(3). Retrieved from http://www.irrd.org/irrd 22/3/more22046.htm.

Muchadeyi, F. C., Wollny, C. B. A., Eding, H., Weigend, S., Makuza, S. M., \& Simianer, H. (2007). Variation in village chicken production systems among agro-ecological zones of Zimbabwe. Tropical Animal Health and Production, 39(6), 453461.

National Bureau of Statistics (2008). Sudan Households Population Census, 2008.

Olwande, P. O., Ogara, W. O., Okuthe, S. O., Muchemi, G., Okoth, E., Odindo, M. O., \& Adhiambo, R. F. (2010). Assessing the productivity of indigenous chickens in an extensive management system in southern Nyanza, Kenya. Tropical Animal Health and Production, 42(2), 283-288.

Saki, A. A., Zamani, P., Rahmati, M., \& Mahmoudi, H. (2012). The effect of cage density on laying hen performance, egg quality, and excreta minerals. Journal of Applied Poultry Research, 21(3), 467-475.

Sambo, E., Bettridge, J., Dessie, T., Amare, A., Habte, T., Wigley, P., \& Christley, R. M. (2015). Participatory evaluation of chicken health and production constraints in Ethiopia. Preventive Veterinary Medicine, 118(1), 117-127.

Smith, A. J. (1992). Integration of poultry production into the agricultural systems. The tropical Agriculturist: Poultry, Pp.179-191.

Swai, E. S., Karimuribo, E. D., Kyakaisho, P. F., \& Mtui, P. F. (2007). Free-range village chickens on the humid coastal belt of Tanga, Tanzania: their roles, husbandry and health status. Livestock Research for Rural Development, 19(8). Retrieved from http://www.Irrd.cipav.org.co//rrd19/8/ swai19104.htm.

Swatson, H. K., Nesamvumi, E., Tshovhote, J., Ranwedzi, N. E., \& Fourie, C. (2003). Growth patterns and dynamics of indigenous chicken under traditional farming systems. National workshop on indigenous poultry development. Pietermaritzburg, South Africa - 29-30 October 2003.

Swatson, K. N., Sahlai, I. V., \& Byebwa, B. K. (2002). Characterization of indigenous free ranging poultry production systems under traditional management conditions in the Vhembe District of the Limpopo Province, South Africa. Fowls for Africa Agriculture Research Council, Pretoria, South Africa. 